\title{
ЛЕЧЕЊЕ ХИПОКАЛИЈЕМИЈЕ
}

\section{Слободан Јанковић}

Факултет медицинских наука, Универзитет у Крагујевцу

\section{TREATMENT OF HYPOKALEMIA}

\section{Slobodan Janković}

Faculty of Medical Sciences, University of Kragujevac

\section{САЖЕТАК}

Нормалне вредности концентрације калијума у серуму се крећу од 3,5 до $5 \mathrm{mM} / \mathrm{L}$, при чему у целом организму човека има око 50 $\mathrm{mM} / \mathrm{kg}$ калијума (98\% се налази унутар ћелија). Вредност концентрације калијума у серуму испод $3,5 \mathrm{mM} / \mathrm{L}$ се назива хипокалијемијом, која постаје тешка ако ниво калијума падне испод $2,5 \mathrm{mM} / \mathrm{L}$. Знаци и тешке хипокалијемије обухватају слабост скелетних мишића, парализе и парезе,депресију и/или психотична стања, асимптоми грчеве, парестезије,опстипацију, мучнину и понекад повраћање, полиурију и полидипсију,.

Поред мерења концентрације калијума у серуму, треба обавезно измерити концентрацију магнезијума, калцијума, фосфата, бикарбоната и глукозе (као и рН крви), јер су поремећаји нивоа ових супстанција често повезани са хипокалијемијом.

Пацијента са хипокалијемијом треба прикључити на ЕКГ мониторинг, обезбедити венску линију и проценити респираторни статус. Благу хипокалијемију обично лечимо корекцијом узрока који ју је изазвао, док је код умеренеобично довољна орална надокнада калијума. Тешку хипокалијемију лечимо парентералном надокнадом калијума. Уколико постоји хипомагнезијемија, надокнада калијума се тешко спроводи, па је потребно кориговати недостатак оба јона.
Приликом интравенске надокнаде калијума користи се стандардни раствор калијум хлорида од 7,4\%, који у једном милилитру садржи 1 мМ калијума.У току дана не треба дати више од 90 мМ калијума, нити се сме прећи брзина интравенске примене од $20 \mathrm{mM}$ на сат. Потребна доза стандардног раствора калијум хлорида се пре примене разблажује у 500 милилитара простог физиолошког раствоpa, који се пре почетка инфузије мора добро промућкати, како не би дошло до таложења калијума.

Кључне речи: хипокалијемија, мишићна слабост, калијум хлорид

\section{ABSTRACT}

Normal serum levels of potassium range from 3.5 to $5 \mathrm{mM} / \mathrm{L}$, and whole body content of potassium amounts to $50 \mathrm{mM} / \mathrm{kg}$ (98\% is located within the cells). Serum levels of potassium below $3.5 \mathrm{mM} / \mathrm{L}$ are classified as hypokalemia, which becomes severe if serum levels drop below $2.5 \mathrm{mM} / \mathrm{L}$.Signs and symptoms of hypokalemia could be: muscle weakness, paresis or paralysis, paresthesias, obstipation, nausea, sometimes vomiting, muscle cramps, polyuria, polydipsia, depression and/or psychotic states.

Besides measuring serum levels of potassium, those of magnesium, calcium, phosphate, bicarbonate (as well as blood $\mathrm{pH}$ ) and glucose 
should also be measured, since their disturbance is often linked to hypokalemia.

A patient with hypokalemia should be connected to ECG monitoring, an intravenous access should be obtained and respiratory status checked. Mild hypokalemia is treated by correction of causes, and moderate by oral potassium supplementation. Severe hypokalemia is treated by intravenous potassium supplementation. If hypomagnesaemia is also present, it should be corrected first, since its correction is prerequisite for normalization of potassium levels.

Intravenous supplementation is performed by potassium chloride ( $7.4 \%$ solution) diluted with $500 \mathrm{ml}$ of simple physiological solution. Daily dose should not overcome $90 \mathrm{mM}$, and administration rate should not be faster than $20 \mathrm{mM}$ per hour. The diluted solution of potassium chloride should be thoroughly mixed before its connection to intravenous set, in order to prevent layering of potassium within the solution.

Key Words: hypokalemia; muscle weakness; potassium chloride

\section{УВОД}

Ниво јона калијума у серуму се нормално одржава у оквиру уског распона, јер су механизми апсорпције, секреције и размене калијума између интраћелијског и екстраћелијског простора добро регулисани хормонским и паракриним механизмима. Свакодневно се у крвоток одрасле особе из гастроинтестиналног тракта апсорбује између 40 и 100 милимола калијума. Када доспе у крвоток после апсорпције, калијум активира два хомеостатска механизма: (1) изазива ослобађање инсулина из бета ћелија панкреаса, који затим доводи до уласка јона калијума у ћелије услед активације $\mathrm{Na}+/ \mathrm{K}+\mathrm{ATP}-\mathrm{aze}$, и (2) стимулише ослобађање алдостерона из надбубрега који затим у дисталним тубулима и сабирним каналићима повећава излучивање калијума у урину. Калијум се највећим делом излучује преко бубрега, скоро 90\%. Пошто бубрег много лакше може да повећа губитак калијума него да га задржи, лако долази до настанка дефицита калијума и хипокалијемије уколико постоје фактори који повећавају излучивање калијума у бубрежним тубулима ${ }^{1}$.

Под хипокалијемијом подразумевамо серумске или плазматске вредности јона калијума ниже од $3,6 \mathrm{mM} / \mathrm{l}^{2}$.Није свеједно да ли је калијум мерен у серуму или плазми, јер су серумске вредности увек нешто мало више због ослобађања калијума из ћелија током процеса коагулације. Симптоми хипокалијемије се јављају тек када ниво калијума падне испод 2,5 mM/1 (тешка хипокалијемија): слабост или парализа мишића, промене у ЕКГ-у, аритмије, полиурија, полидипсија, депресија и/или психотична стања. Механизми настанка хипокалијемије су тројаки: прерасподела јона калијума између екстраћелијског и интраћелијског простора, губитак преко бубрега (примарни и секундарни хипералдостеронизам, ренална тубуларна ацидоза, примена диуретика, примена осмотски активних једињења или хипомагнезијемија) и губитак ван бубрега (повраћање, пролив, губитак преко назогастричне сонде или дијализа). Смањен унос калијума веома ретко доводи до хипокалијемије, јер се организам изванредно прилагођава у таквим стањима и смањује екскрецију калијума на минимум. Да би се одредио узрок хипокалијемије, потребно је да се измери артеријски крвни притисак и ураде најмање следеће биохемијске анализе: ниво калијума и магнезијума у серуму, ниво бикарбоната у серуму, количина излученог калијума у урину за 24 сата, ниво калијума и креатинина у урину, и ниво креатинина у серуму $^{3}$. Уколико је количина калијума излученог у урину за 24 сата мања од 20 милимола или је однос уринарног калијума и креатинина мањи од 2,5 милимола по милимолу, узрок хипокалијемије није губитак преко бубрега.

Најчешћи узроци хипокалијемије су: претерано лучење алдостерона (нпр. Конов синдром), примена диуретика Хенлеове петље у дужем периоду, примена осмотских диуретика у дужем периоду или антибиотика који се не реапсорбују из тубула (пеницилини и аминогликозиди), повраћање, дијареја, ексцесивна секреција слузи са калијумом код вилозних аденома црева и ексцесивно знојење. Инсулин, бета-агонисти и метилксантини повећавају улазак калијума у ћелије из екстраћелијског простора, стварајући тенденцију ка настанку хипокалемије; сличан феномен је описан код пацијената предозираних са антипсихотицима друге генерације, рисперидоном и кветиапином ${ }^{4}$.

\section{ЦИљ РАДА}

Циљ овог прегледног чланка је приказ литературних података о патофизиолошким 
механизмима настанка и искуствима у лечењу хипокалијемије.

\section{ЛЕЧЕЊЕ ХИПОКАЛИЈЕМИЈЕ}

Пре почетка лечења хипокалијемије неопходно је да разлучимо да ли је она последица губитка калијума из организма (било реналним, било екстрареналним путем) или прерасподеле калијума између интра- и екстраћелијског простора. Прерасподела је узрок хипокалијемије ако је пацијент недавно примао инсулин, лекове који стимулишу бетаадренергичке рецепторе или теофилин; тада се терапија састоји у отклањању наведених узрока. Ако се ради о губитку калијума, изгубљену количину калијума коју треба надокнадити применом препарата калијума можемо да проценимо на основу концентрације тог јона у серуму. За сваки $1 \mathrm{mM} / \mathrm{l}$ снижења концентрације калијума у серуму, у организму постоји дефицит калијума од око 4 $\mathrm{mM} / \mathrm{kg}$ телесне тежине. Иначе је дневна потреба за калијумом код здраве одрасле особе око 1 милимол по килограму телесне тежине $\mathrm{e}^{5,6,7}$.

Ако је ниво калијума испод границе када се јављају симптоми хипокалијемије, надокнаду калијума треба извршити интравенским путем.За надокнаду се користи стандардни 7,4\%-тни раствор калијум-хлорида, који у себи садржи 1 милимол калијума на 1 милилитар. Стандардни раствор се пре примене мора разблажити у физиолошком раствору, у количини од 500 милилитара, јер би примена концентрованог раствора интравенски нагло подигла ниво калијума у централном крвотоку и довела до токсичног дејства на срце. Није препоручљиво да се за разблаживање калијум хлорида користи раствор глукозе, јер она подстиче ослобађање инсулина, који потом повећава улазак калијума у ћелије и отежава нормализацију екстраћелијског калијума. Приликом интравенске инфузије физиолошког раствора у који је убачен концентровани раствор калијум хлорида (обично 30 милилитара концентрованог 7.4\%тног раствора на 500 милилитара физиолошког раствора) не треба прећи брзину инфузије од 20 милимола на сат. Најчешће укупно за 24 сата дајемо око 90 милимола калијума; никада не треба прећи више од 200 милимола калијум хлорида на дан, како не би дошло до преласка хипокалијемије у хиперкалијемију. Ако се калијум даје брзо (око 20 милимола на сат), онда треба примену обављати преко централног венског катетера, јер ће у противном доћи до тромбозе периферне вене ${ }^{8}$. Најсигурније је да брзина интравенске примене калијума не прелази 10 милимола на сат.

Када се концентровани калијум хлорид дода у физиолошки раствор, боцу треба енергично промућкати пре прикључења на инфузиони сет, како се калијум хлорид као тежи молекул не би издвојио у доњим деловима боце и тако приликом инфузије дошло до пролазне хиперкалијемије.

Уколико поред хипокалијемије пацијент има и ацидозу, треба прво кориговати хипокалијемију па онда ацидозу. У противном, примена натријум бикарбоната ће довести до додатног уласка калијума у ћелије (због размене са интраћелијским јоном водоника), што ће погоршати хипокалијемију.

Надокнаду калијума оралним путем треба пре свега вршити помоћу намирница богатих калијумом. Неке намирнице су толико богате калијумом да могу заменити таблете са солима калијума, које обично имају 12 милимола калијума по таблети. Тако на пример банана има око 10 милимол калијума, a један печени кромпир чак 22 милимола калијума. Сто педесет милилитара сока од шљива садржи 9 милимола калијума, а иста количина сока од поморанџе има око 4 милимола калијума. Сушено воће, нпр. смокве, урме, шљиве има и преко 25 милимола калијума на 100 грама.Намирнице имају предност над таблетама због значаних нежељених последица примене таблета. После примене таблета са калијумоммогу се јавити мучнина и повраћање, затим гастритис, улцерације на једњаку праћене сужењем лумена због фиброзе, и најзад улцерације дуоденума или јејунума (посебно код таблета са продуженим ослобађањем калијум хлорида). Обично је пацијенту потребно 6 таблета калијум хлорида дневно, од којих свака садржи по 12 милимола калијума. Ако се калијум хлорид примењује у виду прашка за оралну употребу, дневна доза је обично 2-4 грама (тј. 25 до 50 милимола). Дневна доза калијум хлорида треба да се подели на 2 до 4 појединачне дозе.Да би се спречила нежељена дејства, таблете калијум хлорида се дају за време јела, али такав маневар ипак не може сасвим да спречи описана нежељена дејства. Много је сигурније и једноставније дати пацијенту да попије сок или поједе намирницу богату калијумом у одговарајућој количини ${ }^{5}$. У контролисаној клиничкој студији на пацијентима који су 
после кардиохируршке интервенције примали фуросемид упоређена је примена таблета калијум хлорида и намирница богатих калијумом у погледу ефикасности у постизању нормалног серумског нивоа калијума. Студија је показала да су намирнице богате калијумом подједнако ефикасне као таблете калијума у контроли серумског нивоа калијума, али и да су пацијенти који су примали намирнице богате калијумом били краће хоспитализовани ${ }^{9}$

Осим калијум хлорида, у корекцији хипокалијемије која је праћена ацидозом могу се користити и калијум цитрат, калијум бикарбонат или калијум ацетат; уколико код пацијента постоји и хипофосфатемија, надокнаду калијума треба вршити са калијум фосфа-том. У Србији је тренутно регистрован само калијум хлорид, и то орални препарат у виду прашка, као и раствор за парентералну примену у ампулама од 20 милилитара, концентрације од 7,4\%, тј. 1 милимол по милилитру.

Уколико и поред надокнаде калијума његов серумски ниво остаје низак, треба проверити да ли пацијент можда нема и хипокалцемију или хипомагнезијемију. Уколико постоји неки од тих поремећаја треба их кориговати, после чега ће бити могуће нормализовати серумски ниво калијума ${ }^{10}$.

Калијум хлорид не треба примењивати парентерално код пацијената који су на терапији диуретицима који штеде калијум, јер може доћи до хиперкалијемије. Слично се може догодити ако примењујемо калијум хлорид у инфузији пацијентима који су на хроничној терапији са инхибиторима ангиотензин-конвертујућег ензима (АЦЕ-инхибитори) или са блокаторима рецептора за ангиотензин, па је неопходан опрез у таквим ситуацијама ${ }^{11}$. Интеракције калијум хлорида са диуретицима који штеде калијум, са АЦЕ-инхибиторима или са блокаторима рецептора за ангиотензин су посебно честе код особа чија функција бубрега је ослабљена ${ }^{12}$.

\section{ЗАКЉУЧАК}

Лечење хипокалијемије препаратима калијум хлорида је поступак који захтева велики опрез, како у погледу избора дозе, тако и у погледу избора пута и брзине примене. Када је год то могуће, предност треба дати оралном путу надокнаде, а ако је интравенска примена калијум хлорида неизбежна, треба је спроводити постепено, не прелазећи лимит брзине примене скопчан са нежељеним ефектима.

\section{ЛИТЕРАТУРА}

1. Gennari FJ. Disorders of potassium homeostasis. Hypokalemia and hyperkalemia. Crit Care Clin 2002; 18(2):273-88, vi.

2. Gennari FJ. Hypokalemia. N Engl J Med 1998;339(7): 451-8.

3. Hoorn EJ, Tuut MK, Hoorntje SJ, van Saase JL, Zietse $\mathrm{R}$, Geers AB. Dutchguideline for the management of electrolyte disorders -2012 revision. Neth J Med 2013;71(3):153-65.

4. Unwin RJ, Luft FC, Shirley DG. Pathophysiology and management of hypokalemia: a clinical perspective. Nat Rev Nephrol 2011;7(2):75-84.

5. Hainsworth AJ, Gatenby PA. Oral potassium supplementation in surgical patients. Int J Surg 2008;6(4): 287-8.

6. Weiner ID, Wingo CS. Hypokalemia-consequences, causes, and correction. J Am Soc Nephrol 1997;8(7): $1179-88$

7. Cohn JN, Kowey PR, Whelton PK, Prisant LM. New guidelines for potassiumreplacement in clinical practice: a contemporary review by the National Councilon Potassium in Clinical Practice. Arch Intern Med 2000;160(16):2429-36.

8. Lee JW. Fluid and electrolyte disturbances in critically ill patients.Electrolyte Blood Press 2010;8(2):72-81.

9. Norris W, Kunzelman KS, Bussell S, Rohweder L, Cochran RP. Potassiumsupplementation, diet vs pills: a randomized trial in postoperative cardiacsurgery patients. Chest 2004;125(2):404-9.

10. Kokot F, Hyla-Klekot L. Drug-induced abnormalities of potassium metabolism. Pol Arch Med Wewn 2008; 118(7-8):431-4.

11. SAŽETAK KARAKTERISTIKA LEKA. Kalium chlorid Fresenius, koncentrat za rastvor za infuziju, 1 $\mathrm{mmol} / \mathrm{ml}$, Fresenius Kabi Norge AS, Agencija za lekove i medicinska sredstva Srbije, Decembar 2011. [cited 2014 Novembar 8]. Преузето ca: http://www. alims.gov.rs/ciril/files/lekovi/smpc/515-01-5278-11001.pdf.

12. SAŽETAK KARAKTERISTIKA LEKA. Kalii chloridi, oralni prašak, 1 g,UFAR d.o.o., Agencija za lekove i medicinska sredstva Srbije, Avgust 2012. [cited 2014 Novembar 8]. Преузето ca: http://www. alims.gov.rs/ciril/files/lekovi/smpc/515-01-1568-12001.pdf. 